\title{
Appreciation Toward The Sense of Humor Scale Based on Gender and Ethnicity
}

\author{
Unggul Haryanto Nur Utomo \& Ahmad Muhammad Diponegoro \\ Faculty of Psychology, Ahmad Dahlan University \\ unggu185@gmail.com
}

\begin{abstract}
The concern of this research is to examine The Sense of Humor Scale's openness to gender and ethnic. 150 male and 150 female university students from Bugis, Java, Madura, Sambas, Sasak, and Sunda ethnic are randomly divided from 1.179 respondents applying the stratified quota random sampling technique. The collecting data is conducted the site-based and the conventional mode. The difference of appreciation between gender and ethnic toward SHS is tested by using Two-Ways Anova. The coefficient of Cronbach's alphareliability points out SHS 0,961 with 76 figural items (item mortality $0 \%$ ). Range of items discriminating power approximates 0,380 to 0,578 . The difference index of appreciation toward SHS points out based on gender $\mathrm{F}=0,477(\mathrm{p}=0,490)$; among six ethnics $\mathrm{F}=1,028(\mathrm{p}=0,401)$, among gender and six ethnics $\mathrm{F}=1,068(\mathrm{p}=0,378)$. The men and women from the six ethnics have the same appreciation to SHS that it, for the certain level, is funny enough. This research proves that SHS is valid and reliable as the measure of humor appreciation for students and complies the requirement as the opened device to gender and ethnic.
\end{abstract}

Keyword: Appreciation toward SHS, reliable, openness, valid.

\section{BACKGROUND}

Nowdays, the development of the humor sensitivity device is still dominated by scholars from America and Europe. The only humor sensitivity device which was original from Indonesia was the Sense of Humor Scale(SHS) A-B version evolved by Hasanat and Subandi in 1998. It had a purpose to measure the appreciation to humor material (conformist sense), A$\mathrm{B}$ version in which respectively contained 38 figural items (totally 76 items as the whole) such the pictures of cartoon creation from some Indonesian cartoonists.

The conclusion of Utomo's research result toward SHS (2006) is: (1) SHS A-B version (both combined and separated) is reliable as the appreciation device to humor particularly for group subject of students. (2) SHS A-B version consists of four factors/components/categories including violence, annoyance, parody, and joke (totally capacity factor in the amount of 55\%). (3) SHS A-B version is the valid humor sensitivity tool as containing the items which content the funny enough humor. (4) SHS A-B version constitutes the device that is generally open for gender (not susceptible-bias gender). The following research regarding SHS is done in thesis by some students who are under the writer's supervision focused on the experiment of validity and reliability SHS with certain ethnic students. Those pervade 200 Bugis ethnic students (Abdullah, 2014), 211 Java ethnic students (Triyantoro, 2014), 200 Madura ethnic students (Yusnita, 2014), 160 Sambas ethnic students (Susanti, 2014), 204 Sasak ethnic students (Parianti, 2014), and 204 Sunda ethnic students (Kesumasakti, 2014). The six thesis' with the different ethnic background show the similar outcome in which SHS A-B version is valid and reliable as the appreciation humor device and is not gender bias (there is no difference appreciation toward SHS between man and woman subject).
The anyone's test result extremely relies on their culture in which they grow. Each culture strengthens the growth of attitude frequently adopted by cultural value or other sub-culture the origin of culture (Anastasi and Urbina, 2017). Therefore, in this research it is going to examine the appreciation toward SHS based on the variable of gender and six ethnics pervading Bugis, Madura, Jawa, Sambas, Sasak, and Sunda.

\section{Theoretical Framework}

Traditionally, the development of psychology tests cross-culture has endeavored to remove one or more parameter containing the difference among one culture and other cultures which one of them is related to language in use (Anastasi and Urbina, 2007). The research regarding a humor is the research of individual attitude phenomena influenced by the culture background while Indonesia consists of 500 ethnics (Melalatoa, 1995).

SHS has the items consisting of cartoon images without word elements in whatever language to its process. Furthermore, the concern question of this research is: is SHS open for man and woman (the variable of gender) who have the different cultural background such as Bugis, Jawa, Madura, Sambas, Sasak, and Sunda ethnic (the variable of ethnic)?

\section{Research Purpose}

This research has the purpose to test the different appreciation toward SHS between gender and ethnic to Bugis, Madura, Jawa, Sambas, Sasak, and Sunda students.

\section{Research Benefit}

This research gives the reinforcement for the previous research result regarding validity and reliability SHS which extends the pivotal contribution 
in series of cross-cultural study toward SHS as the humor sensitivity device that is original from Indonesia.

\section{The expected Research Outcome} fair).

SHS is open for all of cultures in Indonesia (culture

\section{Theoretical Discourse}

The international psychiatrists and psychologists acknowledge the humor potential that is: a) Humor can build and make the more open and friendly relationship between a therapist expert and his patient, b) Humor can be become as a medium to deploy the fundamental motivation (such libido urge, negative emotion, by the way which is able to be accepted by people), c) It can stimulate someone to raise the creativity by seeing a problem from site of its humor, d) Making anxiety and strain becomes lighter (Bastaman, 2007).

The humor sensitivity device arranged by America and Europe researcher is: 1) Situational Humor Responses Questionnaire(SHRQ) (Martin and Lefcourt, 1984), 2) Coping Humor Scale (CHS) (Martin and Lefcourt, 1983), 3) Sense ofHumor Questionnaire (SHQ) (Svebak in Martin and Lefcourt, 1983), 4) Mindess (Nilsen, 1993) arranged the test tool for measuring adulthood of humor, 5) Thorson and Powell (1996) made up Multidimensional Sense of Humor Scale (MSHS), 6) McGhee dan Panoutsopoulou (1990) used humor stimulation such one buklet containing four cartoon pictures and four jokes, 7) Levine and Redlich (Levine, 1956) exerted cartoon image taken from magazines to highlight the subject response toward humor, 8) Eysenck and Wilson (1982) created the sense of humor scale taking 32 cartoon images.

The Sense of Humor Scale(SHS) was firstly conducted by Hasanat and Subandi in 1998. It had a purpose to measure the appreciation to humor material (conformist sense), A-B version in which respectively contained 38 figural items (totally 76 items as the whole) such the pictures of cartoon creation from some Indonesian cartoonists.

Exploratory factor analysis to SHS was firstly did by Utomo (2006) resulting four components, namely violence, annoyance, parody and joke. The conclusion of Utomo's research outcome is: (1) SHS A-B version (both combined and separated) is reliable as the appreciation device to humor particularly for group subject of students. (2) SHS A-B version consists of four factors/components/categories including violence, annoyance, parody, and joke (totally capacity factor in the amount of 55\%). (3) SHS A-B version is the valid humor sensitivity tool as containing the items which content the funny enough humor. (4) SHS A-B version constitutes the device that is generally open for gender (not susceptible-bias gender).

The following research regarding SHS is conducted in thesis by some students who are under the writer's supervision focused on the examine of validity and reliability SHS with certain ethnic students. Those pervade 200 Bugis ethnic students (Abdullah, 2014), 211 Java ethnic students (Triyantoro, 2014), 200
Madura ethnic students (Yusnita, 2014), 160 Sambas ethnic students (Susanti, 2014), 204 Sasak ethnic students (Parianti, 2014), and 204 Sunda ethnic students (Kusumasakti, 2014). The six thesis with the different ethnic background show the similar outcome in which SHS A-B version is valid and reliable as the appreciation humor device and is not gender bias (there is no difference appreciation toward SHS between man and woman subject).

Several factors influencing someone's humor sensitivity are: a) knowledge, social-cultural background, c) the type of personality, d) certain condition of self disturbance, and e) maturity.

\begin{tabular}{|c|c|c|c|c|}
\hline Etnis & Gender & Mean & $\begin{array}{l}\text { Std. } \\
\text { Deviation }\end{array}$ & $\mathrm{N}$ \\
\hline \multirow[t]{4}{*}{ Bugis } & Men & 241.08 & 31.551 & \multirow[b]{2}{*}{5} \\
\hline & Women & 246.72 & 31.215 & \\
\hline & Total & 243.90 & 31.192 & \\
\hline & & & & 0 \\
\hline \multirow[t]{4}{*}{ Jawa } & Men & 261.64 & 26.539 & 5 \\
\hline & Women & 237.04 & 37.440 & \\
\hline & & & & 5 \\
\hline & Total & 249.34 & 34.438 & 0 \\
\hline \multirow[t]{5}{*}{ Madura } & Men & 235.68 & 45.846 & \\
\hline & & & & 5 \\
\hline & Women & 231.04 & 45.477 & \\
\hline & & & & 5 \\
\hline & Total & 233.36 & 45.254 & \\
\hline \multirow{6}{*}{ Sambas } & Men & 24076 & 48064 & \\
\hline & & & & 5 \\
\hline & Women & 234.28 & 46.747 & \\
\hline & & & & 5 \\
\hline & Total & 237.52 & 47.038 & \\
\hline & & & & 0 \\
\hline \multirow[t]{5}{*}{ Sasak } & Men & 237.04 & 42.135 & \\
\hline & Women & 24380 & 40187 & \\
\hline & & & & 5 \\
\hline & Total & 240.42 & 40.893 & \\
\hline & & & & 0 \\
\hline \multirow[t]{5}{*}{ Sunda } & Men & 234.08 & 45.926 & \\
\hline & Women & 23804 & 37506 & J \\
\hline & & & & 5 \\
\hline & Total & 36.06 & 41.546 & \\
\hline & & & & 0 \\
\hline \multirow[t]{5}{*}{ Total } & Men & 241.71 & 41.189 & \\
\hline & Women & 238.49 & 39.791 & \\
\hline & & & & 50 \\
\hline & Total & 240.10 & 40.461 & \\
\hline & & & & 00 \\
\hline
\end{tabular}

Therefore, the best test device has openness to all of cultures because there is the extensive thoughtfulness related to ability of the available test application for people who are not profited from the cultural aspect (Sarwono, 2005). 


\section{RESEARCH METHOD}

\section{Research Subject}

300 subjects of students ( 150 men and 150 women) from Bugis, Jawa, Madura, Sambas, Sasak, and Sunda ethnics are randomly chosen from 1.179 respondents using the technic combination stratified quota sampling.

\section{The Identification of Research Variable}

Dependent variable:The appreciation to SHS

Independent variable: Gender and Ethnic

\section{Research Design}

This research utilizes the method of quantitative approach. The raw score of each item from 879 subjects used toSHS reliability analysisand total score of 300 subjects used to test of comparative appreciation toward SHS between gender and ethnic.

\section{Instrumentation}

The examined device The Sense of Humor Scale(SHS), containing 76 figural items (cartoon images) which resort the response format of level humor with five options beginning from score 1 (not very funny) to score 5 (very funny). The accumulation of data is with the site and conventional base that can be individually accessed.

The Hypothetical Score of SHS:

Explanation: Xt=Maximum Score, Xr=Minimum Score, $\square=$ average, $\sigma=$ Standard Deviation

\section{Data Analysis Method}

\begin{tabular}{lllll}
\hline SHS & & Interval & Category & core \\
\hline$\square \square$ item & 6 & $319-380$ & Very Funny & 5 \\
Xt & 80 & $258-318$ & Funny & 4 \\
$\mathrm{Xr}$ & 76 & $198-257$ & Funny Enough & 3 \\
$\square$ & 228 & $137-197$ & Not Funny & 2 \\
$\sigma$ & 50,667 & $76-136$ & Not Very Funny & 1 \\
\hline
\end{tabular}

The reliability analysis uses the Cronbach's alpha formula and the comparative test utilizing Two-Ways Anova. The processing of data uses SPSS program 19,0 version.

\section{RESEARCH RESULT AND DISCUSSION}

1. The coefficient of reliability (Cronbach's alpha) SHS is 0,961 with the level of mortality $0 \%$ (no failed item). Range of item discriminating power $\left(\mathrm{r}_{\mathrm{it}}\right)$ is the lowest 0,390 (item number 6) and the highest 0,568 (item number 68 ).

2. The result of Two-Ways Anova appoints the index of different appreciation to SHS, following:

Descriptive Statistic Data: Appreciation to SHS among gender and ethnic

\section{Discussion}

The result of Two-Ways Anova shows that among gender and the six-ethnic has the similar appreciation to humor subject in SHS items. Accordance with this test it can be explained that the stimulation in SHS items appraised funny by men as well as valued funny by women from whereby ethnics among Bugis, Jawa, Madura, Sambas, Sasak, and Sunda ethnic.

The description of statistic data respectively points out the empirical average score of the subject group based on gender and ethnic that exist on the same category with average score of hypothetical SHS. That means that each subject group has appreciation to SHS with the relatively same joke level pervading in funny enough degree.

\begin{tabular}{lccl}
\hline Variable & F & Sig. (p) & Significance \\
& & & \\
\hline \multirow{2}{*}{ Gender } & \multirow{2}{*}{177} & 0,490 & Not Significant \\
Ethnic & 1,028 & 0,401 & Not Significant \\
& & $(\mathrm{p}>0,05)$ & \\
Gender and Ethnic & 1,068 & 0,378 & Not Significant \\
\hline
\end{tabular}

This analysis outcome indicates that SHS constitutes the humor sensitivity device which is not susceptible gender bias for student subjects having background of Bugis, Jawa, Madura, Sambas, Sasak, and Sunda ethnic.

\section{CONCLUSION}

1. SHS is valid and reliable as the humor sensitivity device of students.

2. The male or female students from Bugis, Jawa, Madura, Sambas, Sasak, and Sunda ethnic have the same appreciation regarding humor material in SHS items, namely in funny enough level.

3. SHS complies the requirement as the humor sensitivity tool which is culture fair as it is not gender bias to students of Bugis, Jawa, Madura, Sambas, Sasak, and Sunda.

\section{Suggestion}

1. The next research requires to enggage the other ethnics that represent the various teritories in Indonesia from Sabang until Merauke.

2. It needs to be conducted re-examination regarding nomenclature each factor in SHS blue print by the indigenous method approach.

3. To be required availability and fluency of internet connection as the infrastructure support for the method of accumulation data on line based-site.

\section{REFERENCES}

Abdullah, A. I. (2014). Validitas dan Reliabilitas Skala Kepekaan Humor (SKH) Versi A-B pada Mahasiswa Etnis Bugis. Skripsi (tidak diterbitkan). Yogyakarta: Fakultas Psikologi Universitas Ahmad Dahlan. 
Anastasi, A., \& Urbina, S. (2007). Tes Psikologi (edisi ke-7). Jakarta: Indeks.

Bastaman, H. D. (2007). Logoterapi: Psikologi untuk menemukan makna hidup dan meraih hidup bermakna. Jakarta: PT Raja Grafindo Persada.

Eysenck, H. J. \& Wilson, G. (1982). Know Your Own Personality. England: Penguin Books, Ltd.

Hasanat, N. U \& Subandi. (1998). Pengembangan Alat Kepekaan terhadap Humor. Laporan Penelitian. Yogyakarta: Fakultas Psikologi Universitas Gadjah Mada.

Kusumasakti, W. (2014). Validitas dan Reliabilitas Skala Kepekaan Humor (SKH) Versi A-B pada Mahasiswa Etnis Sunda. Skripsi (tidak diterbitkan). Yogyakarta: Fakultas Psikologi Universitas Ahmad Dahlan.

Levine, J. (1956). Responses to Humor. Scientific American, Vol. 194, No. 6, 31-35.

Martin, R. A. \& Lefcourt, H. M. (1983). Sense of Humor as a Moderator of The Relation between Stressor and Moods. Journal of Personality and Social Psychology, Vol. 45, No. 6, 1313-1324.

Martin, R. A. \& Lefcourt, H. M. (1984). Situational Humor Responses Questionnaire: Quantitative measure of sense of humor. Journal of Personality and Social Psychology, Vol. 47, No. 1, 145-155.

McGhee, P. E. \& Panoutsopoulou, T. (1990). The Role of Cognitive Factors in Children's Metaphor and Humor Comprehension. Humor, 3-4, 379-402.

Melalatoa, M. J. (1995). Ensiklopedi Suku Bangsa di Indonesia. Jakarta: Departemen Pendidikan dan Kebudayaan RI.

Nilsen, D. L. F. (1993). Humor Scholarship: A Research bibliography. London: Greenwood Press.

Parianti, Y. (2014). Validitas dan Reliabilitas Skala Kepekaan Humor (SKH) Versi A-B pada Mahasiswa Etnis Sasak. Skripsi (tidak diterbitkan). Yogyakarta: Fakultas Psikologi Universitas Ahmad Dahlan.

Sarwono, S., W. (2005). Psikologi dalam Praktek (edisi revisi). Jakarta: Restu Agung.

Susanti, S. V. T. (2014). Validitas dan Reliabilitas Skala Kepekaan Humor (SKH) Versi A-B pada Mahasiswa Etnis Sambas. Skripsi (tidak diterbitkan). Yogyakarta: Fakultas Psikologi Universitas Ahmad Dahlan.

Thorson, J. A. \& Powell, F. C. (1996). Women, Aging and Sense of Humor. Humor, 92, 169-186.

Triyantoro, D. B. (2014). Validitas dan Reliabilitas Skala Kepekaan Humor (SKH) Versi A-B pada Mahasiswa Etnis Jawa. Skripsi (tidak diterbitkan). Yogyakarta: Fakultas Psikologi Universitas Ahmad Dahlan.

Utomo, U. H. N. (2006). Validitas dan Reliabilitas Skala Kepekaan terhadap Humor. Tesis (tidak dipublikasikan). Yogyakarta: Universitas Gadjah Mada.

Yusnita, H. (2014). Validitas dan Reliabilitas Skala Kepekaan Humor (SKH) Versi A-B pada Mahasiswa Etnis Madura. Skripsi (tidak diterbitkan). Yogyakarta: Fakultas Psikologi Universitas Ahmad Dahlan. 